\title{
Lactic acid bacteria from Jijel's traditional butter: Isolation, identification and major technological traits
}

\author{
By Tayeb Idoui ${ }^{\text {ab }}$ and Nour-Eddine Karam ${ }^{b}$ \\ a Laboratory of Pharmacology and Phytochemistry, University of Jijel, \\ BP 98 Ouled Aissa, Jijel (18000) Algeria \\ ${ }^{\mathrm{b}}$ Laboratory of Biology of Microorganisms and Biotechnology, University of Oran, (31000), Algeria \\ Corresponding author: tay_idoui @yahoo.fr
}

\section{RESUMEN}

Bacterias acidolácticas de mantequilla tradicional de Jijel: aislamiento, identificación y principales características tecnológicas

Se aíslan veintisiete (27) bacterias acidolácticas de la mantequilla tradicional de Jijel. Éstas pertenecen a los géneros Lactococcus, Lactobacillus y Leuconostoc. Los resultados muestran que Lactobacillus plantarum es la especie predominante en dicha mantequilla. Diversas cepas presentan algunas propiedades tecnológicas interesantes.

PALABRAS CLAVE: Bacterias acidolácticas Identificación - Mantequilla tradicional - Propiedades tecnológicas.

SUMMARY

Lactic acid bacteria from Jijel's traditional butter: Isolation, identification and major technological traits

Twenty seven (27) lactic acid bacteria were isolated from Jijel's traditional butter. These strains belong to three genera: Lactococcus, Lactobacillus and Leuconostoc. The results showed that Lactobacillus plantarum was the predominant species in this traditional butter. It appears that these strains have some interesting technological properties.

KEY-WORDS: Identification - Lactic acid bacteria Technological properties - Traditional Butter.

\section{INTRODUCTION}

Lactic acid bacteria (LAB) occur naturally in several raw materials such as milk, meat and flour (Rodriguez et al., 2000). LAB are used as natural or selected starters in food fermentations in which they perform acidification due to the production of lactic and acetic acids. The protection of food from spoilage and pathogenic microorganisms by LAB is related to their antagonistic activity (Parvez et al., 2006).

LAB play an important role in food fermentation as the fermented products are characterized by hygienic safety, storage stability and attractive sensory properties (Savadogo et al., 2006; Kacem et al., 2004).

Interest in microorganisms as a component of biological diversity has been renewed in recent years.
The interest in the microorganisms occurring in foods is primarily due to the biotechnological potential of new bacterial species and strains (Leisner et al., 1999). LAB are widely distributed in nature and occur naturally as indigenous microflora in raw milk and these gram positive bacteria also play an important role in many food and feed fermentations. Microorganisms of the genera Lactococcus, Lactobacillus, Leuconostoc, Streptococcus and Pediococcus are involved in several fermentations (Soomro and Kiran, 2002).

Fermented dairy products are an important integral part of the diet in Algeria. The major traditional butter produced in Jijel is called "Dhan". Rural people still produce "dhan" by traditional methods using primitive utensils. The raw material is cows' milk, after spontaneous coagulation it is churned and then the butter is recovered.

To our knowledge there is still no information about the lactic acid bacteria of this traditional butter.

The aim of this study is the isolation and identification of lactic acid bacteria from this traditional butter.

\section{MATERIALS AND METHODS}

\subsection{Butter samples}

The butter used in this study was the traditional "dhan" made from raw cows' milk. Five samples of butter were collected from local retailers in the region of Sayda-Zguiwartan, south of Jijel in Algeria.

\subsection{Isolation of bacterial strains}

Samples were heated at $45^{\circ} \mathrm{C}$ and then centrifuged at $3000 \mathrm{rpm}$ for $15 \mathrm{~min}$. The intermediate or central liquid phase was recovered and then five decimal dilutions were carried out (Leveau and Bourgeois, 1980). Dilutions of $10^{-4}$ and $10^{-5}$ were plated in duplicate onto MRS agar and M17 agar. The plates were incubated at $37^{\circ} \mathrm{C}$ for $24 \mathrm{~h}$ in anaerobic conditions.

Twenty seven (27) colonies were picked from the higher dilutions $\left(10^{-5}\right)$ and sub-cultured in MRS and M17 broth. 


\subsection{Physiological and biochemical tests}

The identification of the isolates was performed according to the criteria of Bergey's Manual of Determinative Bacteriology (Holt et al., 1994) and using the methods and criteria of (Sharpe 1979).

The isolates were initially subjected to the Gram staining and the catalase test $\left(3 \% \mathrm{H}_{2} \mathrm{O}_{2}\right)$. Only the Gram positive, catalase negative isolates were further identified. Growth at different temperatures was determined in MRS and $\mathrm{M} 17$ broths at $10^{\circ} \mathrm{C}$, $15^{\circ} \mathrm{C}, 40^{\circ} \mathrm{C}$ and $45^{\circ} \mathrm{C}$. NaCl tolerance $(4 \%$ and $6.5 \%$ ) was performed in MRS and M17 broths; reductase, hydrolysis of arginine and Sherman tests (milk with $0.1 \%$ and $0.3 \%$ of methylene blue) were also recorded. The acetoin production was determinate using the Voges-Proskauer test.

The fermentative type was determined on agar (Gibson and Abdelmalek, 1945). This agar was prepared and autoclaved in accordance with the manufacturer's instructions. Citrate utilization and haemolysis type were also determined.

The ability of the isolated strains to produce acid from different carbohydrates was determined by API $50 \mathrm{CHL} / \mathrm{CHS}$ test kits (BioMerieux, S.A., France). The API test strips were prepared as recommended by the kit supplier and scored after incubation for 24 and 48 hours at $37^{\circ} \mathrm{C}$. The results were loaded onto the API system software, which used the phenotypic data to predict a species identity (\%) for each isolate.

\subsection{Assessment of technological performance of some isolated strains}

The first technological aptitude of the studied isolated strains was evaluated according the terms of the acidification rate and coagulation of skim milk. The determination of the total acidity $\left({ }^{\circ} \mathrm{D}\right)$ was performed by titration with $\mathrm{N} / 9 \mathrm{NaOH}$ in the presence of phenolphtaleine.

The exopolysaccharide production from sucrose was recorded in MRS agar (20 g. $\mathrm{L}^{-1}$ sucrose) for lactobacilli and in M17 agar for Lactococcus and Leuconostoc (Leveau et al., 1991).

The proteolytic activity was evaluated in Yeast Milk Agar (YMA). The diameter of proteolysis zone was determined after incubation at $30^{\circ} \mathrm{C}$ for 24 hours (Vuillemard et al., 1986).

Some isolates were examined for their positive interactions (cooperation) and negative interactions (inhibition) by the direct method according to (Fleming et al., 1975). Isolates to be tested were spotted onto the surface of MRS agar or M17 agar $\left(10^{6}-10^{7} \mathrm{cfu} / \mathrm{ml}\right.$ from 18-hour cultures in MRS or M17 broth) and incubated overnight at $35^{\circ} \mathrm{C}$. Aliquots $\left(0,2 \mathrm{ml}\right.$ of $10^{5}-10^{6} \mathrm{cfu} / \mathrm{ml}$ from 12-hour cultures in MRS or M17 broth) of broth culture were inoculated into soft MRS (or M17) agar (7ml) and poured over the plates on which the putative producer had grown. The plates were incubated at $35^{\circ} \mathrm{C}$ for 24 hours. Inhibition was scored positive if the width of the clear zone around the colonies of the producer strain was $1.5 \mathrm{~mm}$ or larger.

\section{RESULTS}

\subsection{Classification of the isolates}

After a series of purification on MRS agar, twenty-three isolates were found to be Grampositive, catalase-negative, non motile, mesophilic homofermentative bacilli (Table 1). After a series of purification on Elliker medium, four isolates were found to be not motile, Gram positive cocci. These four isolates are able to grow at $10^{\circ} \mathrm{C}$ but not at $45^{\circ} \mathrm{C}$, while three of them perform gamma haemolysis because the medium is not modified (while Streptococcus and Lactococcus are gamma haemolytic) and are heterofermentative (Table 2).

The standard physiological and biochemical tests led to identification of the isolates as follows: twenty isolates of Lactobacillus plantarum $(74.07 \%)$, three isolates of Lactobacillus curvatus $(11.11 \%)$, one isolate of Lactococcus lactis

ssp cremoris (3.70\%), one isolate of Leuconostoc lactis $(3.70 \%)$ and two isolates of Leuconostoc mesenteroides ssp dextranicum $(7.40 \%)$.

The results indicate that members of the same species ( $L$. plantarum) have some different physiological and biochemical characteristics and then the percentage of identification using API strip system software is different too. According to our results, L. plantarum BJ0022 is able to use inuline, methyl D-mannose and D-raffinose and the percentage of identification using API strip system software is $90.9 \%$ while L. plantarum BJ0021 cannot use these three carbohydrates and the percentage of identification is $99.9 \%$.

Lactobacillus plantarum was the predominant species in the traditional butter $(74.07 \%)$, although Lactobacillus curvatus, Lactococcus lactis ssp cremoris, Leuconostoc lactis and Leuconostoc mesenteroides ssp dextranicum were present too.

\subsection{Acid production}

The assessment of the main technological aptitude of some isolated strains was based on the speed of acidification. The time for milk coagulation was used to classify the isolated strains as fast, intermediary and slow acidifying strains. The results showed that Lactobacillus curvatus BJ023 and Lactobacillus plantarum BJ051and BJ0021 are the fastest strains. L. curvatus BJ023 produced $113.33^{\circ} \mathrm{D}$ at the end of 12 hours incubation. These three strains were able to coagulate the milk in less than nine hours. Hence, these isolates were the Fast Acid Producers (FAP). On the other hand, Leuconostoc mesenteroides ssp dextranicum BJ034 was the slowest acidification agent (Figure 1a and Figure 1b)

\subsection{Proteolytic activity}

The isolates were able to grow on the YMA media where bacterial proteolytic activity led to clear zones. As shown in Table 3, the diameters of 
Tabla 1

Physiological and biochemical characteristics of bacilli isolates

\begin{tabular}{|c|c|c|c|c|c|c|c|c|c|c|c|}
\hline Isolates & BJ021 & BJ022 & BJ033 & BJ036 & BJ041 & BJ045 & BJ051 & BJ052 & BJ0021 & BJ0022 & BJ0024 \\
\hline Gram Strain & + & + & + & + & + & + & + & + & + & + & + \\
\hline Cell Shape & Rods & Rods & Rods & Rods & Rods & Rods & Rods & Rods & Rods & Rods & Rods \\
\hline Catalase test & - & - & - & - & - & - & - & - & - & - & - \\
\hline Growth at: & & & & & & & & & & & \\
\hline $15^{\circ} \mathrm{C}$ & + & + & + & + & + & + & + & + & + & + & + \\
\hline $45^{\circ} \mathrm{C}$ & - & - & - & - & - & - & - & - & - & - & - \\
\hline $6.5 \% \mathrm{NaCl}$ & - & - & - & - & - & - & - & - & - & - & - \\
\hline Arginine hydrolysis & + & + & + & $+/-$ & + & + & $+1-$ & + & + & + & $+/-$ \\
\hline $\begin{array}{l}\text { Fermentative type } \\
\text { Fermentation of: }\end{array}$ & $\mathrm{h}$ & $\mathrm{h}$ & $\mathrm{h}$ & $\mathrm{h}$ & $\mathrm{h}$ & $\mathrm{h}$ & $\mathrm{h}$ & $\mathrm{h}$ & $\mathrm{h}$ & h & $\mathrm{h}$ \\
\hline Lactose & + & + & + & + & + & + & + & + & + & + & + \\
\hline Sucrose & + & + & + & + & + & + & + & + & + & + & + \\
\hline Gluconate & $+1-$ & $+1-$ & $+/-$ & $+/-$ & $+/-$ & $+/-$ & $+1-$ & $+/-$ & $+/-$ & $+/-$ & $+/-$ \\
\hline Ribose & $+1-$ & $+/-$ & $+/-$ & $+/-$ & $+1-$ & $+/-$ & $+1-$ & $+/-$ & $+/-$ & $+1-$ & $+/-$ \\
\hline Xylose & - & - & - & - & - & - & - & - & - & - & - \\
\hline $\begin{array}{l}\text { Identification using } \\
\text { API strip system } \\
\text { software }\end{array}$ & $96.9 \%$ & $99.6 \%$ & $99.9 \%$ & $99.8 \%$ & $99.6 \%$ & $99.9 \%$ & $99.9 \%$ & $97.8 \%$ & $99.9 \%$ & $90.9 \%$ & 99.9 \\
\hline Identified as & \multicolumn{11}{|c|}{ Lactobacillus plantarum } \\
\hline
\end{tabular}

h: homofermentative.

Tabla 1 (continued)

Physiological and biochemical characteristics of bacilli isolates

\begin{tabular}{|c|c|c|c|c|c|c|c|c|c|c|c|}
\hline Isolates & BJ0031 & BJ0032 & BJ0034 & BJ0041 & BJ0042 & BJ0331 & BJ0341 & BJ0411 & BJ023 & BJ044 & BJ0231 \\
\hline Gram Strain & + & + & + & + & + & + & + & + & + & + & + \\
\hline Cell Shape & Rods & Rods & Rods & Rods & Rods & Rods & Rods & Rods & Rods & Rods & Rods \\
\hline Catalase test & - & - & - & - & - & - & - & - & - & - & - \\
\hline \multicolumn{12}{|l|}{ Growth: } \\
\hline $15^{\circ} \mathrm{C}$ & + & + & + & + & + & + & + & + & + & + & + \\
\hline $45^{\circ} \mathrm{C}$ & - & - & - & - & - & - & - & - & - & - & - \\
\hline $6.5 \% \mathrm{NaCl}$ & - & - & - & - & - & - & - & - & - & - & - \\
\hline $\begin{array}{l}\text { Arginine } \\
\text { hydrolysis }\end{array}$ & $+/-$ & + & + & $+1-$ & $+/-$ & + & $+1-$ & + & $+1-$ & $+/-$ & $+/-$ \\
\hline $\begin{array}{l}\text { Fermentative } \\
\text { type }\end{array}$ & $\mathrm{h}$ & $\mathrm{h}$ & $\mathrm{h}$ & $\mathrm{h}$ & $\mathrm{h}$ & $\mathrm{h}$ & $\mathrm{h}$ & $\mathrm{h}$ & $\mathrm{h}$ & $\mathrm{h}$ & $\mathrm{h}$ \\
\hline \multicolumn{12}{|l|}{ Fermentation of: } \\
\hline Lactose & + & + & + & + & + & + & + & + & + & + & + \\
\hline Sucrose & + & + & + & + & + & + & + & + & + & + & + \\
\hline Gluconate & $+/-$ & $+/-$ & $+/-$ & $+/-$ & $+/-$ & $+/-$ & $+/-$ & $+/-$ & $+/-$ & $+/-$ & $+/-$ \\
\hline Ribose & $+/-$ & $+/-$ & $+/-$ & $+/-$ & $+/-$ & $+/-$ & $+/-$ & $+/-$ & $+/-$ & $+/-$ & $+/-$ \\
\hline Xylose & - & - & - & - & - & - & - & - & - & - & - \\
\hline $\begin{array}{l}\text { Identification } \\
\text { using API strip } \\
\text { system software. }\end{array}$ & $99.9 \%$ & $93.7 \%$ & $96.9 \%$ & $99.9 \%$ & $99.9 \%$ & $99.6 \%$ & $94.9 \%$ & $99.9 \%$ & $90.5 \%$ & $99.9 \%$ & $93.9 \%$ \\
\hline Identified as & \multicolumn{8}{|c|}{ Lactobacillus plantarum } & \multicolumn{3}{|c|}{ Lactobacillus curvatus } \\
\hline
\end{tabular}

h: homofermentative 
Tabla 2

Physiological and biochemical characteristics of cocci isolates

\begin{tabular}{|c|c|c|c|c|}
\hline Isolates & BJ043 & BJ032 & BJ034 & BJ0044 \\
\hline Gram Strain & + & + & + & + \\
\hline Cell Shape & Cocci & Cocci & Cocci & Cocci \\
\hline Catalase test & - & - & - & - \\
\hline \multicolumn{5}{|l|}{ Growth: } \\
\hline $10^{\circ} \mathrm{C}$ & + & + & + & + \\
\hline $40^{\circ} \mathrm{C}$ & + & - & - & - \\
\hline $45^{\circ} \mathrm{C}$ & - & - & - & - \\
\hline $4 \% \mathrm{NaCl}$ & + & $\mathrm{n}$ & $n$ & $\mathrm{n}$ \\
\hline $6.5 \% \mathrm{NaCl}$ & - & - & - & - \\
\hline \multicolumn{5}{|l|}{ Sherman test } \\
\hline $0.1 \%$ methylene blue & + & $\mathrm{n}$ & $\mathrm{n}$ & $\mathrm{n}$ \\
\hline $0.3 \%$ methylene blue & + & $n$ & $n$ & $\mathrm{n}$ \\
\hline Arginine hydrolysis & + & + & + & $+/-$ \\
\hline Fermentative type & $\mathrm{h}$ & het & het & het \\
\hline Acetoin & - & $n$ & $\mathrm{n}$ & $\mathrm{n}$ \\
\hline Haemolysis type & Gamma & Gamma & Gamma & Gamma \\
\hline Reductase & + & nd & nd & nd \\
\hline Exopolysaccharides production & nd & - & + & + \\
\hline $\begin{array}{l}\text { Identification using API } \\
\text { strip system software }\end{array}$ & $90.1 \%$ & $92.3 \%$ & $98.5 \%$ & $90.8 \%$ \\
\hline Identified as & $\begin{array}{l}\text { Lactococcus lactis } \\
\text { ssp cremoris }\end{array}$ & Leuconostoc lactis & $\begin{array}{r}\text { Leuconosto } \\
d t\end{array}$ & $\begin{array}{l}\text { teroides ssp } \\
\text { Im }\end{array}$ \\
\hline
\end{tabular}

h: homofermentative ; het: heterofermentative ; n: not determined.

the hydrolysis zones were from 0 to $6 \mathrm{~mm}$. Leuconostoc lactis BJ032 showed the highest score (6 mm) while Leuconostoc mesenteroïdes ssp dextranicum BJ0044 showed no proteolytic activity. L. plantarum and L. curvatus BJ023 showed the same scores of protein hydrolysis.

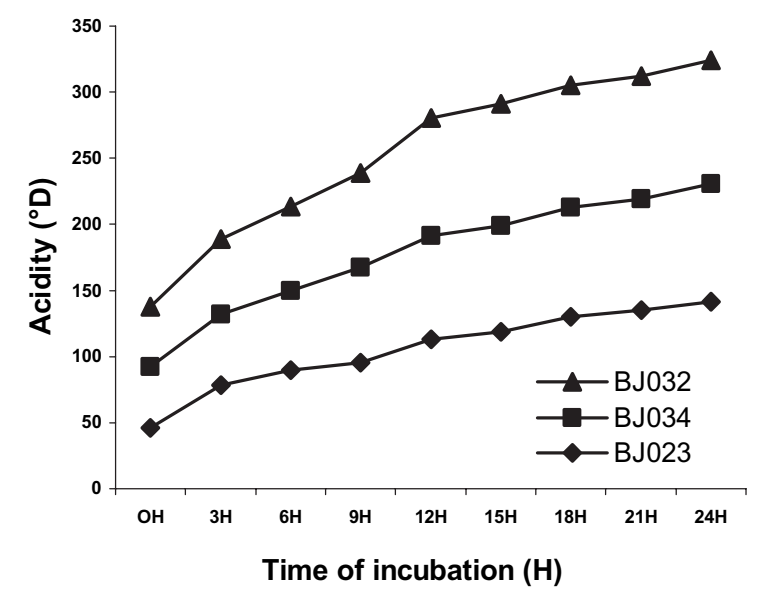

Figure 1a

Production of lactic acid by L.curvatus BJ023,

Ln.mesenteroides ssp.dextranicum BJ034 and Ln.lactis BJ032.

\subsection{Exopolysoccharides production}

Many dairy LAB are able to produce exopolysaccharides (EPS). The strains producing EPS play beneficial roles in the rheological behaviour and texture of the fermented milks. After incubation, all colonies displayed the characteristics

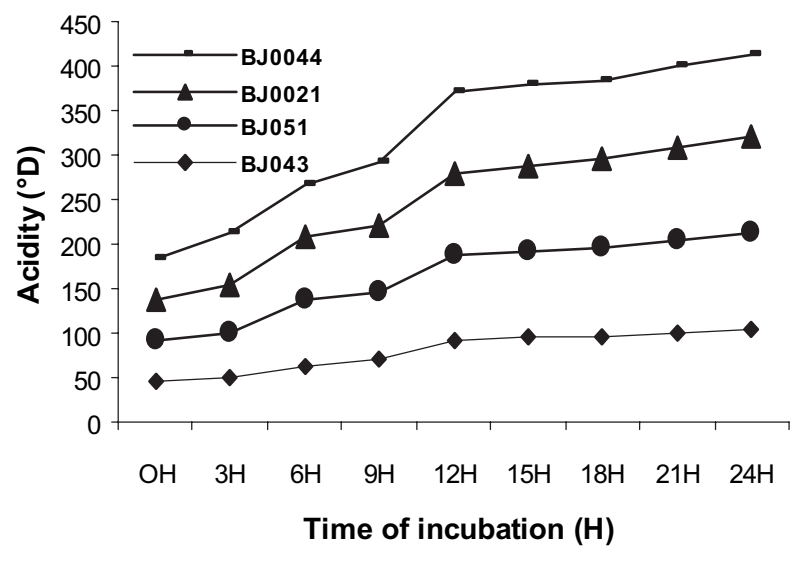

Figure $1 b$

Production of lactic acid by Ln.mesenteroides ssp.dextranicum BJ0044, L.plantarum BJ0021, L.plantarum BJ051 and Ln.lactis ssp.cremoris BJ043. 
of LAB except colonies of Leuconostoc mesenteroides ssp dextranicum BJ034 and BJ0044. The colonies were clearly distinguished (large and pinks colonies) according to their different morphological appearance upon growth in hypersaccharose agar. This could be due to the production of exopolysoccharides.

\subsection{Bacterial interaction}

The ability to produce pure strains should allow for associating them according to technological criteria, or better yet, according to the quality of the mixture. In both cases, the knowledge of interactions between the strains would be beneficial.

Bacterial interactions were recorded and results indicate that some strains of LAB were able to inhibit the growth of others strains as shown in Table 4. Inhibited strains were called indicator isolates. Among all strains, Lactobacillus curvatus BJ023, Lactococcus lactis ssp cremoris BJ043, Leuconostoc mesenteroides ssp dextranicum BJ034 and Lactobacillus plantarum BJ0021 were able to inhibit respectively $6,5,5$ and 5 out of 8 indicator isolates.

Table 3

Proteolytic activity of some lactic acid bacteria

\begin{tabular}{lcc}
\hline Isolates & $\begin{array}{c}\text { Proteolytic } \\
\text { activity }\end{array}$ & $\begin{array}{c}\text { Diameter of } \\
\text { proteolysis zone (mm) }\end{array}$ \\
\hline Leuconostoc mesenteroïdes ssp dextranicumBJ034 & + & 5 \\
Leuconostoc mesenteroïdes ssp dextranicumBJ0044 & - & 0 \\
Leuconostoc lactis BJ032 & + & 6 \\
Lactococcus lactis ssp cremoris BJ043 & + & 5,5 \\
Lactobacillus curvatus BJ023 & + & 5 \\
Lactobacillus plantarum BJ0021 & + & 5 \\
Lactobacillus plantarum BJ052 & + & 5 \\
Lactobacillus plantarum BJ041 & + & 5 \\
\hline
\end{tabular}

(+): Proteolytic activity positive. (-): Proteolytic activity negative.

Table 4

Interactions between some lactic acid bacteria isolates

\begin{tabular}{|c|c|c|c|c|c|c|c|c|}
\hline Strains & $\begin{array}{c}\text { Ln. } \\
\text { mesenteroïdes } \\
\text { ssp. dextranicum } \\
\text { BJ034 }\end{array}$ & $\begin{array}{c}\text { Ln. mesenteroïdes } \\
\text { ssp. dextranicum } \\
\text { BJ0044 }\end{array}$ & $\begin{array}{l}\text { Ln. lactis } \\
\text { BJ032 }\end{array}$ & $\begin{array}{l}\text { Lc. lactis } \\
\text { ssp. } \\
\text { cremoris } \\
\text { BJ043 }\end{array}$ & $\begin{array}{l}\text { L. curvatus } \\
\text { BJ023 }\end{array}$ & $\begin{array}{c}\text { L. } \\
\text { plantarum } \\
\text { BJ0021 }\end{array}$ & $\begin{array}{l}\text { L. plantarum } \\
\text { BJ041 }\end{array}$ & $\begin{array}{l}\text { L. plantarum } \\
\text { BJ052 }\end{array}$ \\
\hline $\begin{array}{l}\text { Ln. mesenteroïdes } \\
\text { ssp. dextranicum } \\
\text { BJ034 }\end{array}$ & + & + & + & + & + & + & + & + \\
\hline $\begin{array}{l}\text { Ln. } \\
\text { mesenteroïdes } \\
\text { ssp. dextranicum } \\
\text { BJ0044 }\end{array}$ & - & + & - & + & + & - & - & - \\
\hline Ln. lactis BJ032 & + & + & + & + & + & + & - & - \\
\hline $\begin{array}{l}\text { Lc. lactis ssp. } \\
\text { cremoris BJ043 }\end{array}$ & - & - & - & + & - & - & - & - \\
\hline $\begin{array}{l}\text { L. curvatus } \\
\text { BJ023 }\end{array}$ & + & + & + & + & + & + & + & + \\
\hline $\begin{array}{l}\text { L. plantarum } \\
\text { BJ0021 }\end{array}$ & + & + & + & + & + & - & + & + \\
\hline $\begin{array}{l}\text { L. plantarum } \\
\text { BJ041 }\end{array}$ & + & - & - & - & + & + & - & + \\
\hline $\begin{array}{l}\text { L. plantarum } \\
\text { BJ052 }\end{array}$ & + & - & - & - & + & + & + & + \\
\hline
\end{tabular}

$(+)$ : Diameter of inhibition $>1.5 \mathrm{~mm}$. (-): Diameter of inhibition $=0 \mathrm{~mm}$. 


\section{DISCUSSION}

From our results, it is clear that lactic acid bacteria were isolated from Jijel's traditional butter. Five LAB species were found which were represented by Lactobacillus plantarum, Lactobacillus curvatus Lactococcus lactis ssp cremoris, Leuconostoc lactis and Leuconostoc mesenteroides ssp dextranicum. These results are not in accordance with various reports indicating that predominant lactic acid bacteria in butter was represented by Lactococcus lactis ssp. cremoris and Lactococcus lactis ssp. diacetylactis (Guiraud, 1998).

These results are also not in complete agreement with those reported by (Sagdic et al., 2002) who isolated lactic acid bacteria from traditional Turkish yayik butter represented essentially by strains of Ln. pseudomesenteroides, Ln. gelidum, L. delbrueckii ssp. bulgaricus and $E$. faecium.

Lactobacillus plantarum was found in the five butter samples. This strain represented $74.07 \%$ of the isolates, $L$. plantarum as well as the other lactobacilli frequently reported to be the dominant microorganisms among the non-starter LAB in long ripening butters or cheeses due to their unique ability to grow in highly hostile environments.

The acidification aptitude (Dornic acidity) of some isolates confirms the weak production of lactic acid. Lactobacillus curvatus BJ023 and Lactobacillus plantarum BJ051, BJ0021 are the fastest isolates. Our results are not in accordance with those reported by (Zambou-Ngoufak et al., 2004) who indicated that Lactobacillus plantarum 162RM has very slow acidification properties (milk coagulation was not obtained after 24 hours of incubation). Contrary results were reported by (Haddadin, 2005) who showed that L. plantarum and $L$. casei were the fastest isolated strains.

In addition, $87.5 \%$ of isolates (7 out of 8 of isolates) showed good proteolytic activity and the highest activity were recorded for Leuconostoc lactis BJ032. (Peterson et al., 1990) reported that important differences exist among species of $L A B$ in terms of types and quantities of peptidase activities.

Two strains, Leuconostoc mesenteroides ssp dextranicum BJ034 and BJ0044, showed their ability to produce exopolysaccharides on M17 media containing $20 \mathrm{~g} . \mathrm{L}^{-1}$ sucrose. These species have interesting textural technological aptitudes; this type of result was also described by (Colman and Ball 1984). In a previous study, (Bouzar et al., 1996) reported that $L$. delbrueckii ssp. bulgaricus CNRZ 1187 and two colonial variants produced different yields of neutral heteropolysaccharides when grown in milk. L. helveticus TY 1-2 produced also exocellular polysaccharide (Yamamoto et al., 1994). The presence of viscous extracellular polysaccharides produced by some culture bacteria was also shown to play an important role in achieving satisfactory firmness and apparent viscosity in yoghurt (Patricia et al., 2002).
Finally we found that our lactic acid bacteria strains produce substances that inhibit the growth of other LAB. These results were in accordance with those reported by (Brink et al., 1994) who indicated that LAB exert strong antagonistic activity against many microorganisms, including food spoilage organisms and pathogens. (Parente and Ricciardi 1999) reported that the ability of lactic acid bacteria to compete and finally dominate in fermented products has been attributed to their inhibitory activity due to a decrease in $\mathrm{pH}$, competition for substrates and/or to a variety of antimicrobial agents. If antagonistic interactions between $L A B$ do not depend on bacteriophages, they are caused by liberation molecules like hydrogen peroxide, organic acids or bacteriocins (Aktypis and Kalantzopoulos, 2003).

\section{CONCLUSION}

Results from this study show the heterogeneity of the lactic acid bacteria in the traditional butter. So, twenty seven isolates were identified; lactobacilli were the predominant $(85.19 \%)$ in this product. In our study, characterization and identification were based on physiological biochemical properties and API strip system software analysis. This method is very useful and remains the most widely recognized approach but the classification of isolates would be confirmed by molecular biology techniques such as 16S RNA studies.

The results of the assessment of the technological aptitude indicate that the acidification kinetic confirm the weak production of lactic acid by some isolates; one showed a good proteolysis activity and solely isolates Leuconostoc mesenteroides ssp. dextranicum BJ034 and BJ0044 showed their ability to produce exopolysaccharide. Also, our lactic acid bacteria isolated from traditional butter exhibited antagonistic activity over other gram positive isolates. For future applications, we would select the best combinations between strains for industrial use.

\section{ACKNOWLEDGMENTS}

This work was supported by ANDRS (code 02/12/01/99038) and MESRS (code CNEPRU F01820060061).

\section{REFERENCES}

Aktypis A, Kalantzopoulos G. 2003. Purification and characterization of thermophilin ST-1, a novel bacteriocin produced by Streptococcus thermophilus ACA-DC 0001. Lait. 83, 365-378.

Bouzar F, Cerning J, Desmazeaud M. 1996. Exopolysaccharide production in milk by Lactobacillus delbrueckii ssp.bulgaricus CNRZ 
1187 and by two colonial variants. J. Dairy Sci. 79, 205-211.

Brink Ten BM, Minekns JMBM, Vander Vossen RJ, Huis in't Veld JHJ. 1994. Anti microbial activity of lactobacilli. J. Appl. Bacteriol. 77, 140-148.

Colman G, Ball LC. 1984. Identification of Streptococci in a medical laboratory. J. Appl. Bacteriol. 57, 1-14.

Fleming HP, Etchells JL, Costilow RN. 1975. Microbial inhibition of isolates of Pediococcus from cucumber brine. Appl. Environ. Microbiol. 30, 1040-1042.

Gibson T, Abdelmalek Y. 1945. The formation of carbon dioxide by lactic acid bacteria and Bacillus licheniformis and a cultural method of detecting the process. J. Dairy. Res. 14, 35-44.

Guiraud JP. 1998. Microbiologie alimentaire. Dunod, Paris, 143-144.

Holt JG, Krieg NR, Sneath PH, Staley JT, Williams ST. 1994. Bergey's manual of determinative bacteriology, Ninth Edition, Williams and Wilkins, London, UK.

Kacem M, Zadi-Karam H, Karam NE. 2004. Isolation of lactic acid bacteria for its possible use in the fermentation of green Algerian olives. Grasas y Aceites 55 (4) 385-393.

Leveau JY, Bourgeois CM. 1980. Techniques d'analyse et de contrôle dans les industries agro alimentaires. Tech et Doc, Lavoisier 334-353.

Leveau JY, Bouix M, De Roissart H. 1991. La flore lactique. Techniques d'analyse et de contrôle dans les industries agro alimentaires. Tech et Doc, Lavoisier 152- 186.

Leisner JJ, Pot B, Christensen H, Rusul G, Olsen JO, Wee BW, Muhammad K, Ghazali HM. 1999. Identification of lactic acid bacteria from Chili Bo, a Malaysian food ingredient. Appl. Environ. Microbiol. 65, 599-605.

Patricia RM, Tuinier R, Kaning M, Zoon P. 2002. Role of exopolysaccharides produced by Lactococcus lactis subsp. cremoris on the viscosity of fermented milk. Int. Dairy. J. 12, 689695.

Parente E, Ricciardi A. 1999. Production, recovery and purification of bacteriocins from lactic acid bacteria. Appl. Microbiol. Biotechnol. 52, 628638.

Parvez S, Malik KA, Kang AH, Kim HY. 2006. Probiotics and their fermented food products are beneficial for health. J. Appl. Microbiol. 100, 11711185.

Peterson SD, Marshall RT, Heymann H. 1990. Peptidase profiling of lactobacilli associated with Cheddar cheese and its application to identification and selection of strains of Cheeseripening studies. J. Dairy. Sci. 73, 1454-1464.

Rodríguez E, González B, Gaya P, Núñez M, Medina M. 2000. Diversity of bacteriocins produced by lactic acid bacteria isolated from raw milk. Int. Dairy. J. 10, 7-15.

Sagdic O, Arici M, Simsek O. 2002. Selection of starters for traditional Turkish yayik butter made from yoghurt. Food Microbiol. 19, 303-312.

Savadogo TO, Ouattara C, To T, Bassole IH, Traore SA. 2006. Bacteriocins and lactic acid bacteria. Afr. J. Biotechnol. 5, 678-683.

Sharpe ME. 1979. Identification of lactic acid bacteria, in Skinner FA, Lovelock DW (Eds), Identification methods for microbiologists, Academic Press, London, pp. 233-259.

Soomro AH, Musad T, Kiran A. 2002. Role of lactic acid bacteria (LAB) in food preservation and human health. Pak. J. Nutr. 1 , 20-24.

Vuillemard JC, Amiot J, Gauthier S. 1986. Evaluation de l'activité protéolytique de bactéries lactiques par une_méthode de diffusion sur plaque. Microbiol. Alim. Nutr. 3, 327-332.

Yamamoto Y, Murosaki S, Yamauchi R, Kato K, Sone Y. 1994. Structural study on exocellular polysaccharide produced by Lactobacillus helveticus TY 1-2. Carbohydr. Res. 261, 67-78.

Zambou-Ngoufak F, Nour El Noda A, MbianpoTchouanguep F, El-Soda M. 2004. Effect of ropy and capsular exopolysaccharides producing strain of Lactobacillus plantarum 162RM on characteristics and functionality of fermented milk and soft kareish type cheese. Afr. J. Biotechnol. 3, 512-518.

Recibido: $18 / 2 / 08$ Aceptado: $17 / 4 / 08$ 